\title{
Mechanical Behavior of Particle Reinforced Thermoplastic Matrix Composites Using Finite Element Modeling
}

\author{
K. Mansouri1 ${ }^{1 *}$, H. Djebaili ${ }^{2, \dagger}$, M. Brioua ${ }^{1}$ \\ 1 University Mostefa BENBOULAID Batna 2, 05000, Algeria \\ ${ }^{2}$ University Abbes Laghrour Khenchela, 40000, Algeria
}

(Received 28 April 2020; revised manuscript received 15 October 2020; published online 25 October 2020)

\begin{abstract}
Particles are becoming increasingly popular reinforcing elements in products made by injection molding. Particles reinforcement allows the thermoplastic to be processed employing the same methods as those used for unreinforced thermoplastic. Ultrafine particles, whose diameters are comparable to the crystalline regions in the polymer, have a prominent reinforcing effect on the elastic properties of the polymer. Small particles adhere strongly to the polymer, which leads to a strong reinforcing effect. In particle reinforced thermoplastic matrix composites, loads are not directly applied to the particles but are applied to the matrix, and some of the applied loads are transferred to the particles. The process of transfer of load between particles and matrix depends on the strength of the interface. In this work, multiparticle composite model was analyzed under tensile load. The purpose of this work is to analyze the influence of particle diameter (the diameters of 19.61, 26.15, 39.22 and $78.45 \mu \mathrm{m}$ were used) on the Von Mises stress of glass particle reinforced thermoplastic nylon 66 matrix composite using finite element analysis (FEA). The second objective is to analyze the effect of particle packing (square, hexagonal and random arrangement) on nanocomposite behavior.
\end{abstract}

Keywords: Nanomaterials, Composite materials, Glass particles, Thermoplastic matrix, Finite element.

\section{INTRODUCTION}

Addition of rigid reinforcement into polymeric materials is an established practice in the polymer industry. By introduction of a stiff second phase, substantial improvements in stiffness, strength, creep performance, fracture toughness etc. can be obtained. The reinforcement is often in the form of spheres, plates or fibers. Fibers are often used as reinforcement, although this often results in anisotropic properties. This may lead to problems and variation in component dimensions. Particulate fillers in the form of spheres or plates can therefore sometimes be a better choice when close tolerances or isotropic properties are required [1].

In fact, thermoplastics can be repeatedly softened by increasing temperatures and hardened by cooling, contrary to thermosets which, once cured, cannot be reshaped or remold at elevated temperatures [2]. Thermoplastics have many advantages over metal parts including weight, ease of fabrication and economy. Although the advantages have allowed them to proliferate in various industries, the lack of structural load carrying capacity has hindered their use in automotive and aerospace industries [3]. Some of the material demands in the advanced industries cannot be fulfilled by monolithic materials. Therefore, composite materials have been developed. The combination of desired properties of thermoplastics and glass particles (high strength and high modulus) is the aim of composites production [4]. The high costs and technical difficulties involved in the fabrication of fiber-reinforced composites sometimes limit their use in many applications [5]. Particle reinforced materials are more attractive due to their cost-effectiveness, isotropic properties, and their ability to be processed using similar technol- ogy used for monolithic materials [6].

Particles are used to increase the modulus of the matrix, decrease the permeability and also decrease the ductility. A particle may have either a dimension or no long dimension. Composites consist of particles of one material dispersed in the matrix of the second material. Generally, particles are spherical, ellipsoidal, polyhedral, or irregular in shape. Particles are added to the liquid matrix that later solidifies in some process. The particles may be treated or untreated during reinforcement. Particles are used to increase the strength or other properties of inexpensive materials during reinforcement with other matrix materials [7] (Fig. 1).

The purpose of this work is to analyze the particle diameter and packing effect of glass particle reinforced nylon 66 (PA) matrix composites considering the interaction between the matrix and particles interface. Particle reinforced composite is subjected to the longitudinal tensile loading.

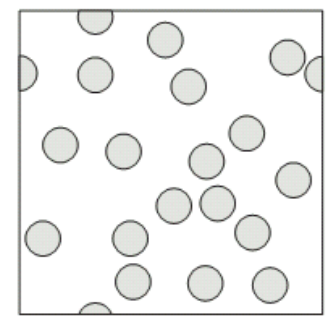

Fig. 1 - Example of the composite reinforced with particles

\section{ANALYTICAL ANALYSIS}

In fact, the stress is higher in the material with the higher elastic modulus (usually the fiber) [8]. The bond-

\footnotetext{
*khelifab700@yahoo.fr

$\dagger$ h_djebaili@yahoo.fr
} 
ing of fiber-matrix can be improved by increasing the contact surface area between the matrix and fiber [9], and the same thing for nanocomposites, when the particles diameter decreases with increasing contact surface area. Factors like type, size distribution, agglomeration state/dispersion, chemical deposition, crystal structure, surface area, surface chemistry, surface charge, shape/morphology, dissolution/solubility, physical/chemical properties of nanoparticles affect the property of composite material characteristics [10].

The development of micromechanics equations for the particulate composites follows along the same lines as those for the short fiber reinforced composites, where the particles are assumed to be arranged in a regular array pattern like square or hexagon. The distance between particles decreases when the volume fraction increases. At higher particles volume fraction the spacing becomes very small [8]. In the theoretical analysis, particles are modeled to be uniformly packed in regular arrangements with each particle having a circular cross-section and the same diameter. The particle volume fraction $\left(V_{p}\right)$ of these ideal arrangements can be computed as

$$
\begin{gathered}
V_{p m h}=(\pi / 2 \sqrt{3})\left(r / R_{\min }\right)^{2} \quad \text { (Hexagonal), } \\
V_{p m s}=(\pi / 4)\left(r / R_{\min }\right)^{2} \text { (Square) }
\end{gathered}
$$

where $2 r$ is the diameter of the particles and $2 R$ is the center to center spacing of nearest neighbor particles. Rearranging equations (2.1) and (2.2) give the expressions for the separation of particles $(s)$ into two ideal arrangements:

$$
\begin{gathered}
s=2\left[\left(\pi / 2 \sqrt{3} V_{f}\right)^{1 / 2}-1\right] r \quad \text { (Hexagonal) } \\
s=2\left[\left(\pi / 4 V_{f}\right)^{1 / 2}-1\right] r \quad \text { (Square) }
\end{gathered}
$$

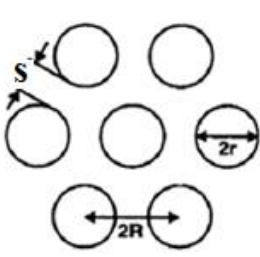

(a)

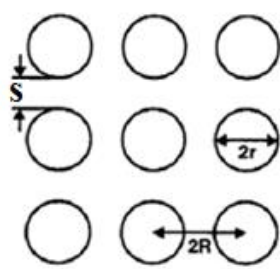

(b)
Fig. 2 - Distance between particles in (a) hexagonal and (b) square packing

These ideal packing arrays are generally used to develop micromechanical models due to their simplicity. However, they are not observed in real composites except in a few localized regions. The mix of arrays in a cross-section varies with the particle volume fraction and the spacing between adjacent particles and can be related to the particle volume fraction empirically [11]:

$$
s=2\left[\left(1.8-0.75 V_{f}\right) V_{f}\right]^{-1 / 2}
$$

One of the main consequences of non-uniformity of packing is the difficulty of achieving volume fractions greater than 0.7 , which is regarded as the practical limit for commercial materials. Packing uniformity is also an important factor in processing operations such as resin transfer molding.

Paluch [12] suggested that the most rational way of analyzing packing uniformity is to determine the distributions of the number of near neighbors $\left(N_{b}\right)$, interparticle distance $\left(D_{r}\right)$ and angle between two particles $(\beta)$. These quantities are defined in Fig. 3. In this method, the polished section is divided into Dirichlet cells, one per particle cross-section, which contains all space closer to that particle than to any other.

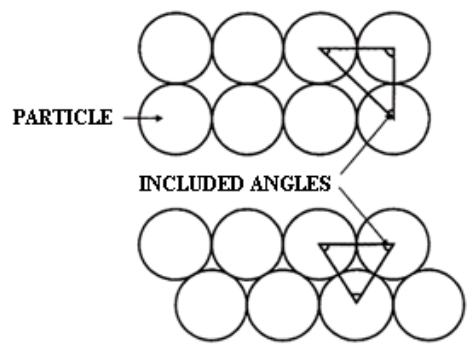

Fig. 3 - Definition of included angle

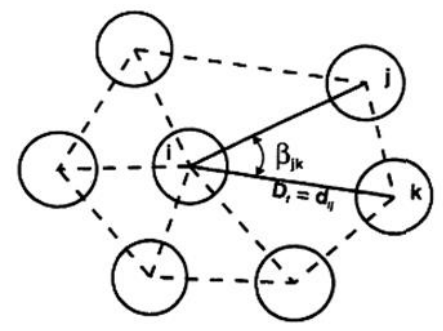

Fig. 4 - Distance and angle between two particles

Each particle can be joined to its closest neighbors to form a network of interparticle distances. Fig. 4 shows the associated triangulated network prepared from the same micrograph. The interparticle distances $\left(D_{r}\right)$ can be determined. Since two particles cannot interpenetrate one another, the minimum value of $D_{r}$ is one particle diameter.

In what follows, we will study the particle diameter and dispersion effect on the mechanical behavior of a composite. The matrix is assumed to have square form with length $l_{m}=155.425 \mu \mathrm{m}$ and volume fraction will be constant $\left(V_{f}=20 \%\right)$ (Fig. 5). The advantage of reducing the diameter of the particle is that the contact area between the particles and the matrix is increased, which implies an increase in the number of particles for the same volume fraction $\left(V_{p}\right)$, while the total mass of the composite remains the same

$$
\begin{gathered}
V_{f}=V_{\text {particle }} / V_{\text {total }}=N_{p}\left(\pi d_{p}^{2} / 4\right) / l_{m}{ }^{2}, \\
d_{f}=\sqrt{4 V_{f} l_{m}{ }^{2} / N_{f} \pi}
\end{gathered}
$$

where $N_{p}$ is the number of particles; $V_{f}$ is the particle volume fraction; $l_{m}$ is the matrix length; $d_{p}$ is the particle diameter; $V_{\text {particle }}$ is the particle volume; $V_{\text {total }}$ is the composite volume. 


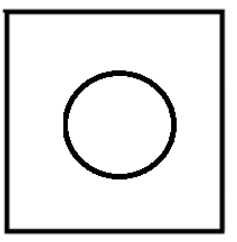

(a)

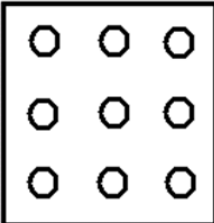

(c)

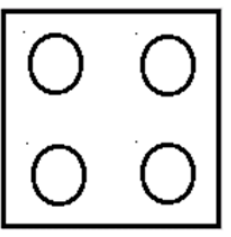

(b)

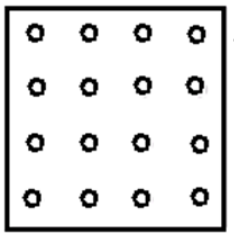

(d)
Fig. 5 - Principe of reducing particle diameter

Table 1 - Composite dimensions for different particles

\begin{tabular}{|c|c|c|c|c|}
\hline$N_{p}$ & $V_{f}(\%)$ & $l_{m}(\mu \mathrm{m})$ & $d_{p}(\mu \mathrm{m})$ & $r_{p}(\mu \mathrm{m})$ \\
\hline 1 & 20 & 155.425 & 78.45 & 39.22 \\
\hline 4 & 20 & 155.425 & 39.22 & 19.61 \\
\hline 9 & 20 & 155.425 & 26.15 & 13.07 \\
\hline 16 & 20 & 155.425 & 19.61 & 9.80 \\
\hline
\end{tabular}

\section{FINITE ELEMENT MODELING}

All the finite element models had a homogeneous distribution of reinforcement particles. The finite element software CASTEM was used to develop the models and generate the results. Composites with four different diameters of circular glass particles of 19.61, 26.15, 39.22 and $78.45 \mu \mathrm{m}$ were modeled. Composites were modeled and meshed with triangular elements to achieve the best convergence and accuracy of the results. The composite was subjected to a uniform tensile stress $\sigma$.

\subsection{Composite Property}

Each element will have an isotropic property. The model is small, so a fine mesh of elements was used [13]. For simplicity, it is assumed that all particles have the same diameter $d_{p}$ [14]. Due to axisymmetry, the specimen can be considered as a $2 \mathrm{D}$ elastic body. The following parameters are used in all calculations [15]:

1. Reinforced glass particles with Young's modulus $E_{p}=64 \mathrm{GPa}$, Poisson ratio $v_{p}=0.2$ and density $\rho_{p}=2.54 \mathrm{~g} / \mathrm{cc}$.

2. Matrix is nylon 66 (PA) with Young's modulus $E_{m}=3 \mathrm{GPa}$, Poisson ratio $v_{m}=0.35$ and density $\rho_{m}=1.14 \mathrm{~g} / \mathrm{cc}$.

\subsection{Boundary Conditions}

The boundary conditions represent the application of tensile loads to particles-filled composite, i.e. $x=0$ and $x=l_{m}, U_{y}=0$, matrix and particle have zero movement in the $Y$-direction (Fig. 6). Here the $X$-axis is in the direction of length and the model is axis-symmetric to it. We have applied $F_{x}=5.65 \cdot 10^{-8} \mathrm{~N} / \mu \mathrm{m}^{2}$ [16] to the end faces of the matrix i.e. at $x=0, x=l_{m}$.

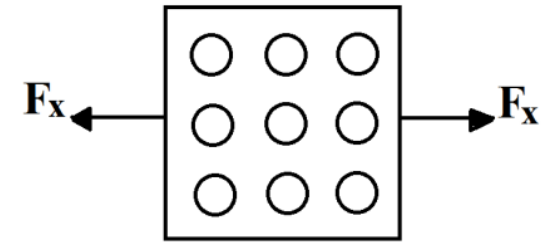

Fig. 6 - Boundary conditions for the composite reinforced with nine particles

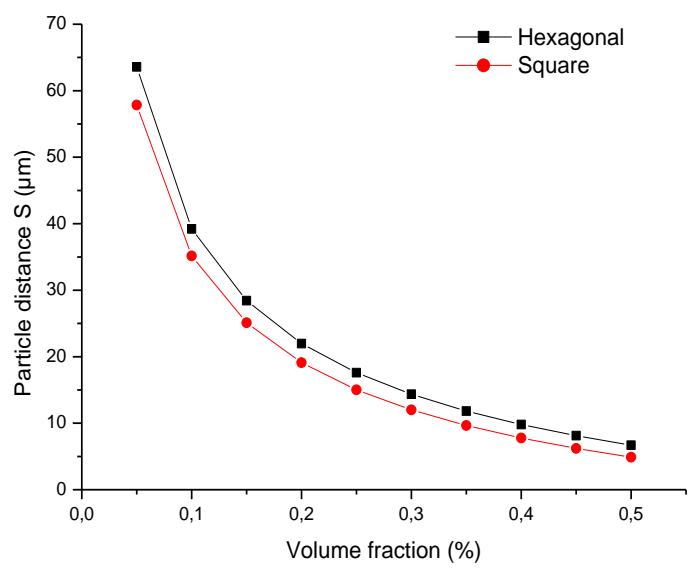

Fig. 7 -Evolution of volume fraction on spacing between particles

\section{RESULTS AND DISCUSSION}

The first objective of this study is to analyze the particle diameter effect on Von Mises and longitudinal stresses of composites made of 1, 4, 9 and 16 glass particles reinforced thermoplastic nylon 66 matrix under tensile loading.

From equations (2.3) and (2.4), the distance between particles is calculated for the two types of packing (hexagonal and square). In Fig. 7, the distance $s$ between particles decreases when the volume fraction increases. At higher particle volume fractions, the spacing becomes very small.

From the simulation realized, high stress concentrations are located in the particles and in matrix zone situated between the particles, in contrary to the composite reinforced with short fibers, where the concentrations of stress are in fiber ends, and the same thing for the longitudinal stress. The effect of particle diameter $(78.45,39.22,26.15$ and $19.61 \mu \mathrm{m})$ on Von Mises and longitudinal stresses of glass/nylon66 composite is shown in Fig. 8. It is seen that the stresses are not very much affected by particle diameter. When particle diameter decreases, the stresses increase, which means that there are no benefits in particle diameter reduction for thermoplastic matrix.

The second objective is to analyze the influence of particle arrangement. In what follows, hexagonal and random arrangement will be simulated to compare the result with that used in square packing saving the same dimension and volume fraction $V_{f}=20 \%$ (Fig. 9).

Fig. 10 represents the evolution of Von Mises stress on volume fraction. When volume fraction increases the Von Mises stress decreases for the three arrangements. 
We can see that random packing (which is more likely in real composite) is situated between the two regular arrangements (square and hexagonal).

It is seen from Fig. 11 that when volume fraction increases, the longitudinal stress decreases too for the three arrangements. Fig. 12 represents the evolution of Young's modulus with volume fraction. It can be seen that Young's modulus in hexagonal packing is superior to other arrangements because the distance between particles $s$ is less in this arrangement.

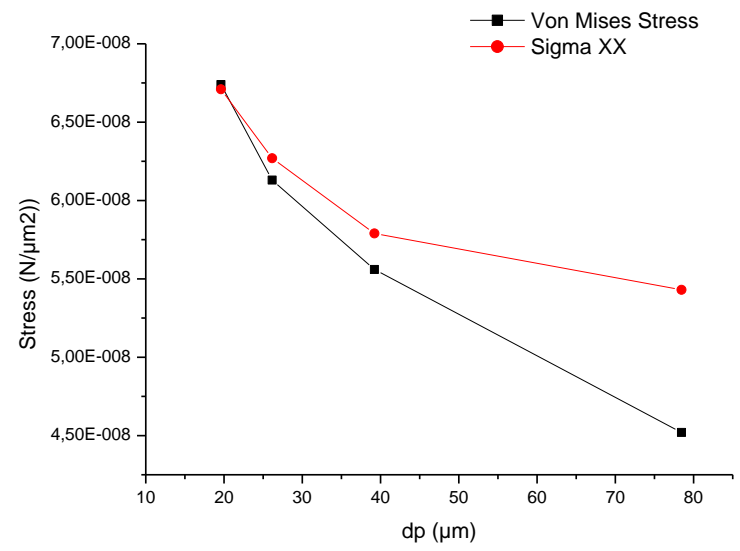

Fig. 8 - Evolution of Von Mises and longitudinal stresses on particle diameter

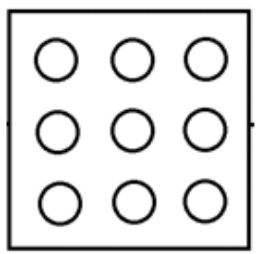

(a)

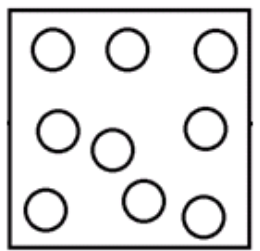

(b)

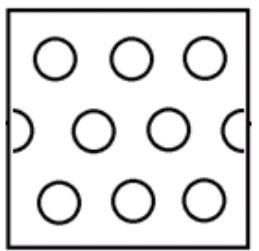

(c)
Fig. 9 - Particles packing: (a) square, (b) random, (c) hexagonal

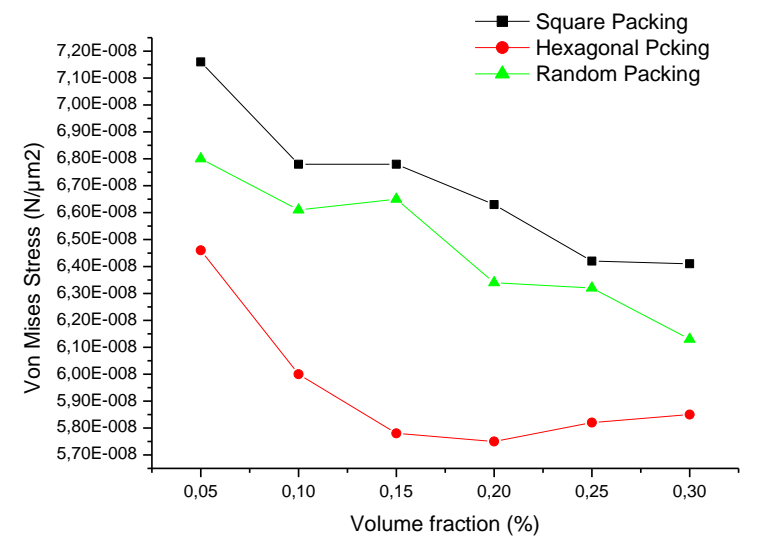

Fig. 10 - Evolution of Von Mises stress on volume fraction

\section{CONCLUSIONS}

In literature, a number of theories and equations have been developed to describe the mechanical behavior

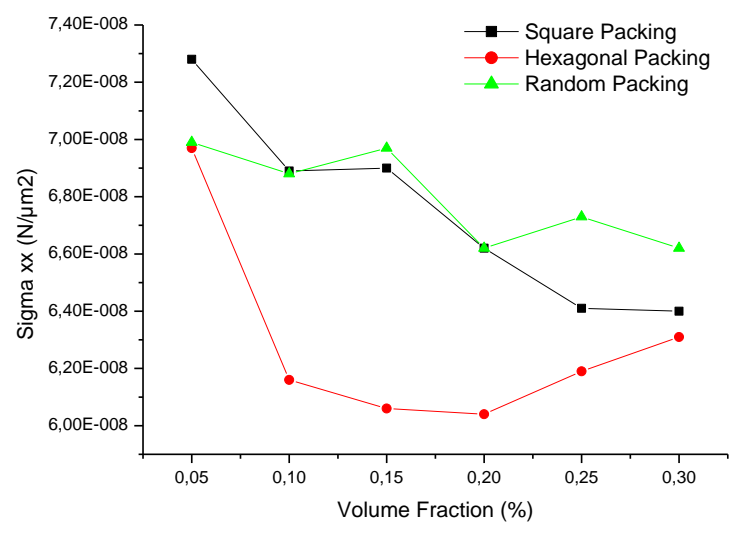

Fig. 11 - Evolution of longitudinal stress on volume fraction

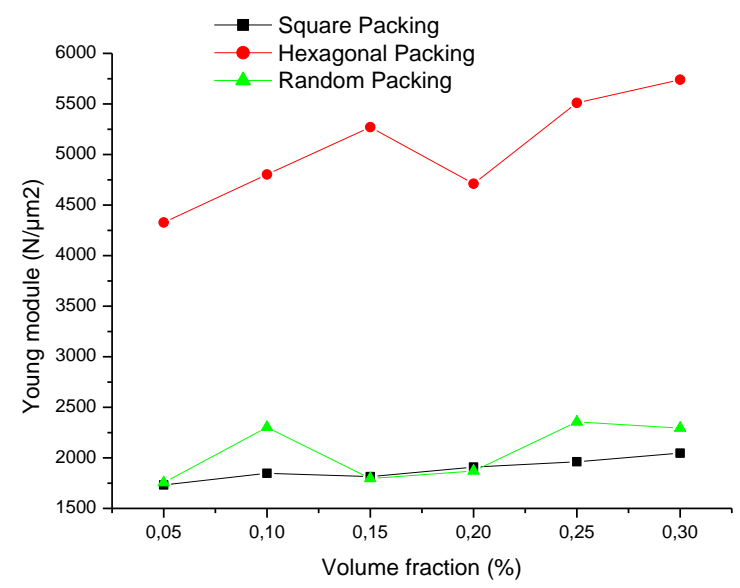

Fig. 12 - Evolution of Young's modulus on volume fraction

of polymer particle composites. Much of the modeling done for metal matrix composites and ceramic matrix composites have also been used for polymer matrix composites. Addition of rigid particles to thermoplastic matrix can positively influence a number of properties like stiffness, creep and fracture toughness.

This study concerns the evolution of Von Mises stress in thermoplastic matrix composite reinforced by glass particles. Since the particles and matrix often have quite different elastic moduli, then the stress in each must be different. In fact, the stress is higher in the material with the higher elastic modulus (usually the particle). The elastic modulus of glass is much greater than that of the nylon 66 matrix. From the preceding discussion, it can be seen that a decrease in the particle diameter does not affect the composite. The results from the finite element modeling (FEM) indicate that, for the same volume fraction and applied load, an increase in strength is also shown with decreasing particle diameter.

The Young's modulus is a function of the particle diameter for constant volume fraction filler. A higher modulus is observed with both an increase in the filler size and increase in the amount of filler in a composite made of glass and nylon. 


\section{REFERENCES}

1. A. Sjögren, Failure Behaviour of Polypropylene/Glass Bead Composites (Luleå University of Technology S-971 87 Luleå: Sweden: 1995).

2. K. Slim, Prom. Micromechanical modeling of the progressive failure in short glass-fiber reinforced thermoplastics (Doghri: Issam: Delannay: Laurent: 2011).

3. A. Kulkarni, N. Aswini, C.R. Dandekar, S. Makhe, International Conference on Structural Nano Composites (NANOSTRUC 2012).

4. N. Parvin, M. Rahimian, Acta Phys. Pol A 121 No 1, 108 (2012).

5. Subodh K. Mital, Pappu L.N. Murthy, Robert K. Goldberg, NASA (1996).

6. Nikhilesh Chawla, Yu-Lin Shen, Adv. Eng. Mater. 3 No 6, 357 (2001).

7. A. Kanagaraj, C. Franciskennathamreth, M. Ajithkumar, V. Anandh, R. Nagaraj, IJRAIIT 5 No 2, 280 (2019).
8. K. Mansouri, H. Djebaili, M. Brioua, RCMA 27 No 3/4, 261 (2017).

9. Mulugeta H. Woldemariam, Giovanni Belingardi, Ermias G. Koricho, Daniel T. Reda, AIMS Mater. Sci. 6 No 6, 1191 (2019).

10. C.S.C. Santos, B. Gabriel, M. Blanchy, O. Menes, D. Garcia, M. Blanco, N. Arconada, Mater. Today Proc. 2, 456 (2015).

11. A. Spencer, Compos. Sci. Technol. 27, 93 (1986).

12. B. Paluch, J. Compos. Mater. 30 No 4, 454 (1996).

13. S. Houshyar, R.A. Shanks, A. Hodzic, EXPRESS Polym. Lett. 3 No 1,2 (2009).

14. H.F. Lei, Z.Q. Zhang, B. Liu, CSTE 72, 506 (2012).

15. J.F. O'Gara, Glen E. Novak, M.G. Wyzgoski, Delphi Research Labs (2010).

16. Prince, M. Verma, S. Singh, IJERA, 287 (2012).

\title{
Механічна поведінка зміцнених частинками термопластичних матричних композитів 3 використанням моделювання методом кінцевих елементів
}

\author{
K. Mansouri ${ }^{1}$, H. Djebaili ${ }^{2}$, M. Brioua ${ }^{1}$ \\ 1 University Mostefa BENBOULAID Batna 2, 05000, Algeria \\ 2 University Abbes Laghrour Khenchela, 40000, Algeria
}

\begin{abstract}
Частинки стають все більш популярними армуючими елементами у виробах, виготовлених методом лиття під тиском. Зміцнення частинками дозволяе обробляти термопластик із застосуванням тих самих методів, що і для неармованого термопластика. Ультрадисперсні частинки, діаметр яких порівнянний з кристалічними областями в полімері, мають помітний зміцнюючий ефект на еластичні властивості полімеру. Дрібні частинки міщно прилипають до полімеру, що призводить до сильного зміцнюючого ефекту. У зміцнених частинками термопластичних матричних композитах навантаження не прикладаються безпосередньо до частинок, а прикладаються до матриці, і частина прикладеного навантаження передається частинкам. Процес передачі навантаження між частинками та матрицею залежить від міцності поверхні розділу. У роботі модель багаточастинкового композиту була проаналізована при розтягуючому навантаженні. Метою даної роботи є аналіз впливу діаметра частинок (використовували частинки 3 діаметрами 19.61, 26.15, 39.22 та 78.45 мкм) на напруження фон Мізеса термопластичного матричного композиту із нейлону 66, армованого частинками скла, з використанням методу кінцевих елементів (FEA). Друга мета роботи полягае в аналізі впливу упаковки частинок (квадратне, шестикутне та випадкове розташування) на поведінку нанокомпозитів.
\end{abstract}

Ключові слова: Наноматеріали, Композитні матеріали, Частинки скла, Термопластична матриця, Кінцевий елемент. 